\title{
INVESTIGATION OF SOME SURFACE PROPERTIES AND THERMOGRAVIMETRIC ANALYSIS OF VENEER SHEETS TREATED WITH FIRE RETARDANTS
}

\author{
Aydin Demir ${ }^{l}$, Ismail Aydin ${ }^{1, \star}$
}

\begin{abstract}
This study investigated the effects of different fire retardant chemicals on surface and thermal properties of veneer sheets. Beech (Fagus orientalis), alder (Alnus glutinosa), poplar (Populus deltoides) and scots pine (Pinus sylvestris) were chosen as wood species and zinc borate, borax, monoammonium phosphate and ammonium sulfate were chosen as fire retardant chemicals. The samples were impregnated by using the immersion method. Some surface properties such as colour measurements and surface roughness of the veneer sheets were conducted according to CIE $L * a * b *$ system. Some thermal properties such as thermal conductivity of the veneer sheets were conducted according to standard and weight loss after combustion was determined by thermogravimetric analysis. Conforming to the results from the study, it was found that fire retardant chemicals increased the thermal conductivity and surface roughness of veneer sheets. Also, thermogravimetric analysis experiments showed that all of the fire retardant chemicals decreased the loss in weights.
\end{abstract}

Keywords: Colour measurement, plywood, surface roughness, thermal conductivity, urea formaldehyde.

\section{INTRODUCTION}

Wood and wood based panels have long been used as materials in the construction industry because they have a great durability, high strength and versatility (Stevens et al. 2006). Plywood, a wood based product, is one of the most important building and furniture materials (Fateh et al. 2013). Compared with solid wood, the chief advantages of plywood are that the properties along the length of the panel are more nearly equal to properties along the width, there is greater resistance to splitting, and the form permits many applications where large sheets are desirable (Aydin and Colakoglu 2008). There are some unfavorable characteristics of the plywood similar to wood and other wood-based composite panels. It can be combusted easily, and this is one of the undesired characteristics of plywood (Ozkaya et al. 2007). The flammability and combustibility properties of such a solid material can be reduced by several recommended treatments (Fateh et al. 2013). The treatment with fire retardant chemicals is the most effective process to protect wood and wood based products from fire is. Therefore, use of fire retardant chemicals has been increased. It has also risen due to awareness of environmental protection and consumer safety, requirement standards which have been raised accordingly. Moreover, capability and properties of fire retardant chemicals such as being harmless to human, animals, and plants with less release of smoke and toxic gases when burned are important parameters for consumers to select a fire retardant chemical. It was also shown the fire retardant chemicals have an effect on other physical, mechanical and some technological properties of the materials treated with them. Inorganic based fire retardant chemicals are extensively used in forest industry because they have both good thermal stability, less release of smoke, less corrosive toxic gases and less strength loss (He et al. 2014, Yao et al. 2012).

Thermal conductivity is the flow of thermal energy through a unit thickness of a material under a temperature gradient and is expressed by the coefficient of thermal conductivity (Kollman and Cote 1968). It is a very important parameter in determining heat transfer rate and is required for development of drying models in industrial operations such as adhesive cure rate (Kol and Altun 2009). Also, it must be known when choosing the insulation materials to attenuate fluctuation in the outdoor environment

${ }^{1}$ Karadeniz Technical University, Faculty of Forestry, Department of Forest Industry Engineering, Trabzon, Turkey.

"Corresponding author: iaydin@ktu.edu.tr

Received: 04.10.2017 Accepted: 22.07.2018 
which maintains an indoor temperature that is independent of outdoor temperature fluctuations. The materials used for insulation must have good warmth-keeping properties such as lower thermal diffusivity to provide sufficient protection from severe temperature changes (Kawasaki and Kawai 2006). Wood materials possess superior thermal conductivity properties compared to other building materials due to its porous structure (Gu and Zink-Sharp 2005, Kruger and Adriazola 2010). They are one of the preferred materials in many applications such as construction industry, refrigerators, automobile industry, and in the manufacture of barrels, because of their low thermal conductivity and high resistance (Gu and Zink-Sharp 2005). Thermal conductivity of wood materials varies according to wood type, direction of wood fiber, resin type, and additive members used in the manufacture of wood composite panels (Kamke and Zylkowoski 1989).

The studies about thermal degradation of solid wood, wood based products or their by-products are necessary for construction fire safety to under-stand the comportments of those materials in case of fire. Thermogravimetric analysis (TGA) is a traditional method to investigate thermal degradation by determining the characteristics of weight loss in different heating rates and atmosphere conditions (Fateh et al. 2013). TGA can be tested with milligram-sized samples. Milligram size samples of materials can be rapidly manufactured and allow to regulate several formulations with fire retardant chemicals to be studied for degradation before full manufacture of the material is undertaken. TGA measurements can provide the pyrolysis rates and mechanisms and char yield in nitrogen at heating rates from 5 to $200^{\circ} \mathrm{C} / \mathrm{min}$ (Hagen et al. 2009).

Environmental factors and treatment conditions such as UV light, heat, moisture, alkali or acids during steaming, preservative treatment, drying or finishing can cause changes in properties of wood and wood based products (Aydin and Colakoglu 2005, Burtin et al. 1998). These changes are generally physical and chemical changes which especially bring about a loss of original colour and surface fibers, and graying (Yildiz et al. 2013). Colour is a basic visual property which can be distinguished easily by consumers for wood and wood based products. Colour measurement is one of the quality control tests. The colour harmony of constituents is significant when assembling individual pieces into final products (Aydin and Colakoglu 2005, Resch et al. 2000). Recently, market requirements have been demanding that producers supply lumber and panel which is attractive, and of specified, uniform and replicable colour (Yeo and Smith 2003). Also, colour of material can cause a change in price of wood (Ishiguri et al. 2003). Surface roughness of veneers plays an important role in plywood manufacture. Cross grain, annual ring width, rays, knots, reaction wood, ratio of early wood and late wood, pre-treatment and peeling conditions, such as knife angle, are some of the raw material and production parameters influencing roughness of veneer. Control of veneer surface in plywood production is essential to maintain plywood quality (Ayrilmis et al. 2006).

Although there are lots of studies in literature about fire retardant chemicals, effects of fire retardant chemicals on thermal and surface properties of wood and wood based panels are not comprehensively investigated. The aim of this study is to increase the knowledge of effects of fire retardant chemicals on thermal and surface properties of veneer sheets. For this aim, four fire retardant chemicals and four wood species widely used in the plywood industry were used and the technological test methods thermal conductivity, TGA, surface roughness and colour measurement were applied.

\section{MATERIALS AND METHODS}

The wood species widely used in the plywood industry in Turkey were chosen as material. Beech (Fagus orientalis Lipsky), alder (Alnus glutinosa subsp. barbata) and poplar (Populus deltoides I-77/51 clone) were obtained as hardwood and Scots pine (Pinus sylvestris L.) was obtained as softwood. Zinc borate, borax, monoammonium phosphate (MAP) and ammonium sulfate were used as fire retardant chemicals. The chemical and physical properties of the fire retardant chemicals used are given in Table 1 (these properties were supplied from the producers). 
Table 1: Properties of fire retardant chemicals.

\begin{tabular}{|c|c|c|c|c|}
\hline $\begin{array}{l}\text { Fire } \\
\text { retardant } \\
\text { Chemicals }\end{array}$ & \multicolumn{2}{|c|}{ Chemical properties } & \multicolumn{2}{|l|}{ Physical properties } \\
\hline Zinc Borate & $\begin{array}{l}\text { Purity grade }(\min \%) \text { : } \\
\mathrm{B}_{2} \mathrm{O}_{3}(\min \%): \\
\mathrm{ZnO}(\min \%):\end{array}$ & $\begin{array}{c}99,90 \\
46 \\
36\end{array}$ & $\begin{array}{l}\text { Molecular weight }(\mathrm{g} / \mathrm{mol}) \\
\text { Specific gravity }(\mathrm{gr} / \mathrm{cc}): \\
\text { Solubility }\left(\% \text { at } 20^{\circ} \mathrm{C}\right) \text { : }\end{array}$ & $\begin{array}{c}434,66 \\
2,79 \\
<0,28\end{array}$ \\
\hline Borax & $\begin{array}{l}\text { Purity grade }(\min \%) \text { : } \\
\mathrm{B}_{2} \mathrm{O}_{3}(\min \%): \\
\mathrm{Na}_{2} \mathrm{O}(\min \%):\end{array}$ & $\begin{array}{l}99,90 \\
36,47 \\
16,24\end{array}$ & $\begin{array}{l}\text { Molecular weight }(\mathrm{g} / \mathrm{mol}) \\
\text { Specific gravity }\left(\mathrm{gr} / \mathrm{cm}^{3}\right) \\
\text { Bulk density }\left(\mathrm{gr} / \mathrm{cm}^{3}\right):\end{array}$ & $\begin{array}{c}381,37 \\
1,72 \\
0,882\end{array}$ \\
\hline MAP & $\begin{array}{l}\text { Purity grade }(\min \%) \text { : } \\
\mathrm{N}(\min \%): \\
\mathrm{P}_{2} \mathrm{O}_{5}(\min \%):\end{array}$ & $\begin{array}{l}99,00 \\
12 \\
61\end{array}$ & $\begin{array}{l}\text { Molecular weight }(\mathrm{g} / \mathrm{mol}) \\
\text { Melting temperature }\left({ }^{\circ} \mathrm{C}\right) \\
\text { Specific gravity }\left(\mathrm{gr} / \mathrm{cm}^{3}\right)\end{array}$ & $\begin{array}{c}115,03 \\
190 \\
1,803\end{array}$ \\
\hline $\begin{array}{l}\text { Ammonium } \\
\text { sulfate }\end{array}$ & $\begin{array}{l}\text { Purity grade }(\min \%) \text { : } \\
\mathrm{NO}_{3}(\min \%): \\
\text { Free } \mathrm{H}_{2} \mathrm{SO}_{4}(\max \%) \text { : }\end{array}$ & $\begin{array}{l}99,00 \\
20,3 \\
0,03\end{array}$ & $\begin{array}{l}\text { Molecular weight }(\mathrm{g} / \mathrm{mol}) \\
\text { Melting temperature }\left({ }^{\circ} \mathrm{C}\right) \text { : } \\
\text { Moisture }(\max \%) \text { : }\end{array}$ & $\begin{array}{c}132,14 \\
280 \\
0,2\end{array}$ \\
\hline
\end{tabular}

\section{Manufacturing and treatment of veneer sheets}

In this experimental study, rotary cut veneer sheets with dimensions of $0,2 \times 50 \times 50 \mathrm{~cm}$ thickness were obtained from freshly cut logs. While the alder and poplar veneers were manufactured from freshly cut logs, beech and Scots pine logs were steamed for $12 \mathrm{~h}$ before veneer production. The horizontal opening between knife and nosebar was $85 \%$ of the veneer thickness, and the vertical opening was $0,5 \mathrm{~mm}$ in rotary cutting process. The veneers were then dried to $6-8 \%$ moisture content with a veneer dryer. After drying, veneer sheets were treated with some fire retardant chemicals. For this aim, $5 \%$ aqueous solutions of zinc borate, borax, monoammonium phosphate (MAP) and ammonium sulfate were used. The veneers were subjected to re-drying process at $110^{\circ} \mathrm{C}$ and then conditioned to $5-7 \%$ moisture content again after they were immersed in the fire retardant solutions for 20 minutes. Twenty samples from each group were used to determine the level of retention. The retention level for each treatment solution was calculated with the following Equation 1, and they were presented in Table 2.

$$
R=\frac{G x C}{V} x 10 \mathrm{~kg} / \mathrm{m}^{3}
$$

where; $\mathrm{R}$ is the retention level $\left(\mathrm{kg} / \mathrm{m}^{3}\right), \mathrm{G}$ is the treatment solution absorbed by the sample in grams, $\mathrm{C}$ is the preservative or preservative solution in $100 \mathrm{~g}$ treatment solution, $\mathrm{V}$ is volume of sample in $\mathrm{cm}^{3}$.

Table 2: Retention levels of fire retardant chemicals.

\begin{tabular}{|c|c|c|c|c|c|}
\hline $\begin{array}{l}\text { Veneer } \\
\text { Species }\end{array}$ & $\begin{array}{c}\text { Fire } \\
\text { retardant } \\
\text { Chemicals }\end{array}$ & $\begin{array}{l}\text { Average } \\
\text { retention } \\
\left(\mathrm{kg} / \mathbf{m}^{3}\right)\end{array}$ & $\begin{array}{l}\text { Veneer } \\
\text { Species }\end{array}$ & $\begin{array}{c}\text { Fire } \\
\text { retardant } \\
\text { Chemicals }\end{array}$ & $\begin{array}{c}\text { Average } \\
\text { retention } \\
\left(\mathrm{kg} / \mathbf{m}^{3}\right)\end{array}$ \\
\hline \multirow{4}{*}{$\begin{array}{l}\text { Beech } \\
\text { (Fagus } \\
\text { orientalis } \\
\text { Lipsky) }\end{array}$} & Zinc borate & 12.58 & \multirow{4}{*}{$\begin{array}{c}\text { Alder } \\
\text { (Alnus } \\
\text { glutinosa } \\
\text { subsp. } \\
\text { barbata) }\end{array}$} & Zinc borate & 15.80 \\
\hline & Borax & 13.28 & & Borax & 13.75 \\
\hline & MAP & 8.71 & & MAP & 10.60 \\
\hline & $\begin{array}{l}\text { Ammonium } \\
\text { sulfate }\end{array}$ & 9.10 & & $\begin{array}{l}\text { Ammonium } \\
\text { sulfate }\end{array}$ & 10.74 \\
\hline \multirow{4}{*}{$\begin{array}{c}\text { Poplar } \\
\text { (Populus } \\
\text { deltoides I- } \\
77 / 51 \\
\text { clone) }\end{array}$} & Zinc borate & 13.49 & \multirow{4}{*}{$\begin{array}{l}\text { Scots pine } \\
\text { (Pimus } \\
\text { sylvestris } \\
\text { L.) }\end{array}$} & Zinc borate & 18.22 \\
\hline & Borax & 10.51 & & Borax & 15.97 \\
\hline & MAP & 10.76 & & MAP & 9.06 \\
\hline & $\begin{array}{c}\text { Ammonium } \\
\text { sulfate }\end{array}$ & 11.03 & & $\begin{array}{l}\text { Ammonium } \\
\text { sulfate }\end{array}$ & 17.94 \\
\hline
\end{tabular}

\section{METHODS}

\section{Colour measurement}

The colour measurements were carried out using a Minolta CM- 2600d spectrophotometer, equipped with an integrating sphere according to the CIE L*a*b* system (HAL 1996). Three samples from each group were used to determine the change of colour. Measurements were made over an $8 \mathrm{~mm}$ 
diameter spot with $10^{\circ}$ observer angle. The colour coordinates of each sample were measured before and after treatment of the veneer sheets at the same point. The $\Delta \mathrm{L}^{*}, \Delta \mathrm{a}^{*}$, and $\Delta \mathrm{b}^{*}$ colour coordinates, therefore total colour change $\left(\Delta \mathrm{E}^{*}\right)$ occurring in the specimens due to the treatment, were calculated on the tangential surface of replicates by comparing them to their initial values.

\section{Surface roughness}

A fine stylus-type profilometer, Mitutoyo Surftest SJ-301 Surface Roughness Tester was used for the surface roughness test. Rz parameter (mean of the 10-point height of irregularities) was used to evaluate surface roughness of the samples according to DIN 4768 (1990). Ten samples at dimensions of $300 \times 300 \times 2 \mathrm{~mm}$ were used for each test group to evaluate surface roughness. Measurements were taken perpendicular to the grain.

\section{Thermal conductivity}

The thermal conductivity of plywood was determined according to ASTM C-518 (2004). Two specimens with the dimensions of $300 \times 300 \times 2 \mathrm{~mm}$ were used for each group. The Lasercomp Fox-314 Heat Flow Meter shown in Figure 1 was used for the determination of thermal conductivity.

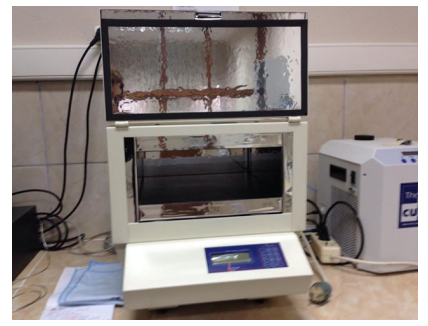

Figure 1: Lasercomp Fox-314 heat flow meter.

\section{Thermogravimetric analyzes (TGA)}

The thermogravimetric analysis measurements were carried out using a TG/DTA 6300 (Seiko Instruments Inc. - SII NanoTechnology Inc., Japan). Before measurements, the samples of each group were powdered. About 5-10 mg of the wood powder was weighed in a platinum cup and scanned from room temperature $\left(20^{\circ} \mathrm{C}\right)$ to $800^{\circ} \mathrm{C}$ at a heating rate of $20^{\circ} \mathrm{C} / \mathrm{min}$. The samples were measured in an atmosphere of nitrogen. The maximum thermal degradation rate was calculated as mass (\%) at peak temperature divided by peak temperature.

\section{RESULTS AND DISCUSSION}

\section{Surface properties of veneer sheets}

The Rz (mean of the 10-point height of irregularities) and the $\Delta \mathrm{L}^{*}, \Delta \mathrm{a}^{*}$, and $\Delta \mathrm{b}^{*}$ colour coordinates, therefore total colour change $\left(\Delta \mathrm{E}^{*}\right)$ occurring in the specimens due to the treatment, were calculated and these values are shown in Table 3 .

Table 3: Surface properties changes of veneer sheets with treated different fire retardant chemicals.

\begin{tabular}{|c|c|c|c|c|c|c|}
\hline Veneer species & Fire retardants & $\mathbf{R z}$ & $\Delta \mathbf{L}^{*}$ & $\Delta a^{*}$ & $\Delta \mathbf{b}^{*}$ & $\Delta \mathbf{E}^{*}$ \\
\hline \multirow{5}{*}{$\begin{array}{c}\text { Beech } \\
\text { (Fagus orientalis } \\
\text { Lipsky) }\end{array}$} & Untreated control & 90.28 & & & & \\
\hline & Zinc borate & 112.07 & 2.29 & -1.30 & -4.56 & 5.27 \\
\hline & Borax & 121.43 & -11.57 & 5.25 & 9.53 & 15.87 \\
\hline & MAP & 107.20 & -4.55 & 4.43 & 9.67 & 11.57 \\
\hline & Ammonium sulfate & 103.20 & -4.83 & 4.62 & 10.26 & 12.23 \\
\hline \multirow{5}{*}{$\begin{array}{c}\text { Alder } \\
\text { (Almus glutinosa } \\
\text { subsp. barbata) }\end{array}$} & Untreated control & 70.92 & & & & \\
\hline & Zinc & 82.28 & 0.37 & -0.64 & -12.87 & 12.9 \\
\hline & Borax & 99.19 & -12.27 & 2.73 & 0.28 & 14 \\
\hline & MAP & 88.10 & -9.47 & 2.61 & -1.72 & 10.03 \\
\hline & Ammonium sulfate & & -4.11 & 2.87 & 2.39 & 5.57 \\
\hline \multirow{5}{*}{$\begin{array}{c}\text { Poplar } \\
\text { (Populus deltoides } \\
\text { I-77/51 clone) }\end{array}$} & Untreated control & 85.91 & & & & \\
\hline & Zinc borate & 96.56 & 7.05 & -3.28 & -9.71 & 12.43 \\
\hline & Borax & 126.26 & 1.46 & -1.76 & -0.87 & 2.48 \\
\hline & MAP & 105.34 & -4.90 & 3.09 & 7.69 & 9.67 \\
\hline & Ammonium sulfate & 120.33 & 3.79 & -2.27 & 0.66 & 4.48 \\
\hline \multirow{5}{*}{$\begin{array}{c}\text { Scots pine } \\
\text { (Pinus sylvestris } \\
\text { L.) }\end{array}$} & Untreated control & 76.60 & - & - & - & - \\
\hline & Zinc borate & 148.57 & 4.97 & -5.52 & -8.39 & 11.32 \\
\hline & Borax & 91.35 & & 0.51 & 1.21 & 8.36 \\
\hline & MAP & 111.07 & -3.89 & 2.35 & 3.32 & 5.65 \\
\hline & Ammonium sulfate & 95.65 & -5.39 & 2.81 & 3.98 & 7.30 \\
\hline
\end{tabular}


According to Table 3, the fire retardant chemicals increased the surface roughness of the veneer sheets. The highest values of surface roughness were found for beech, alder and poplar veneers treated with borax and scots pine veneers treated with zinc borate. Ayrilmis et al. (2006) reported that fire retardant chemicals increased the surface roughness of veneer sheets. Dundar et al. (2008) also found that surface roughness of LVLs made from fire-retardant treated veneers was significantly increased as compared to untreated control specimens and this difference increased with increasing drying temperature. The second drying process performed after the impregnation may also have contributed to increase in surface roughness. Aydin (2004) indicated that the effects of fire retardant chemicals on surface roughness varied according to steaming pre-treatment and veneer drying temperature.

Positive and negative values show a tendency of wood surface to become reddish and greenish for $\Delta \mathrm{a}^{*}$, and yellowish and bluish for $\Delta \mathrm{b}^{*}$, respectively (HAL 1996). Treatment with zinc borate caused surfaces to become greenish and bluish in the all of veneer sheets. Borax, monoammonium phosphate and ammonium sulfate caused surfaces to become reddish and yellowish both for beech and scots pine veneers. In literature, Scots pine showed the yellowish and reddish hues due to impregnation (Simsek and Baysal 2012). In the alder veneers, borax and ammonium sulfate caused surfaces to become reddish and yellowish while monoammonium phosphate caused surfaces to become reddish and bluish. Borax caused surfaces to become greenish and bluish while monoammonium phosphate caused surfaces to become reddish and yellowish in the poplar veneers. Also, ammonium sulfate caused surfaces to become greenish and yellowish. Negative lightness stability $\left(\Delta \mathrm{L}^{*}\right)$ indicates a tendency of a wood surface to become darker (HAL 1996). Treatment with borax, monoammonium phosphate and ammonium sulfate caused surfaces to become darker in the all of veneer sheets except poplar. Simsek and Baysal (2012) found that borate treatments darkened both beech and Scots pine surfaces. In the poplar veneers, only monoammonium phosphate caused surfaces to become darker. The lowest darkening $\left(-\Delta \mathrm{L}^{*}\right)$ and total colour change $\left(\Delta \mathrm{E}^{*}\right)$ were observed with borax for beech and alder veneers. Aydin and Colakoglu (2005) stated that the reason for this could be the water-soluble extractive contents of beech and alder wood. In the poplar veneers, these values were obtained from monoammonium phosphate and zinc borate, respectively. They were obtained from ammonium sulfate and zinc borate in the Scots pine veneers, respectively.

\section{Thermal properties of veneer sheets}

\section{Thermal conductivity}

According to wood species and fire retardant chemicals, the thermal conductivity mean values of veneer sheets are given in Figure 2.

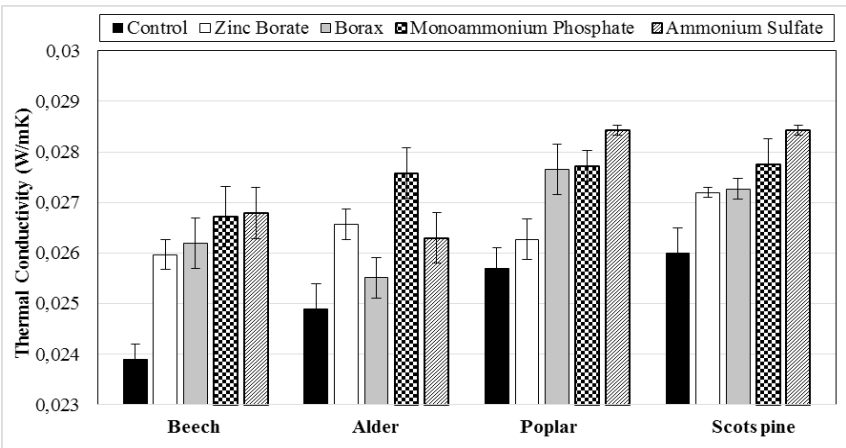

Figure 2: Thermal conductivity changes of the veneer sheets.

As can be seen from Figure 2, the highest values of thermal conductivity were obtained with ammonium sulfate for beech, poplar and scots pine veneers and monoammonium phosphate for alder veneers. When all test groups analyzed, untreated (control) groups were found to have the lowest thermal conductivity values. In the past studies, it was stated that thermal conductivity values of veneer sheets increased with impregnation, because the air in the cell lumen is replaced with a material having a better thermal conductivity (Kol et al. 2008). Another study suggests that fire retardants cause thermal conductivity to increase so that heat is absorbed by the chemical to prevent the wood surface from igniting (Rowell and Levan-Green 2005). Ozdemir et al. (2013) also found that thermal conductivity 
of high density fiberboard increased with using fire retardant chemicals and when the concentration of these chemicals increased, the thermal conductivity values increased. The differences among the thermal conductivity values in the study groups were very small. The reason for this is the low retention levels. Uysal et al. (2008) stated in their study that thermal conductivity values increased when retention levels were increased.

\section{Thermogravimetric analyzes (TGA)}

The temperature of the initial weight loss of pyrolysis $\left(\mathrm{T}_{\mathrm{i}}\right)$, maximum degradation temperature $\left(\mathrm{T}_{\max }\right)$, weight loss at maximum degradation temperature $\left(\mathrm{W}_{\max }\right)$ and residual char at $800^{\circ} \mathrm{C}$ are given in Table 4. Figure 3 also show thermogravimetry curves according to wood species.
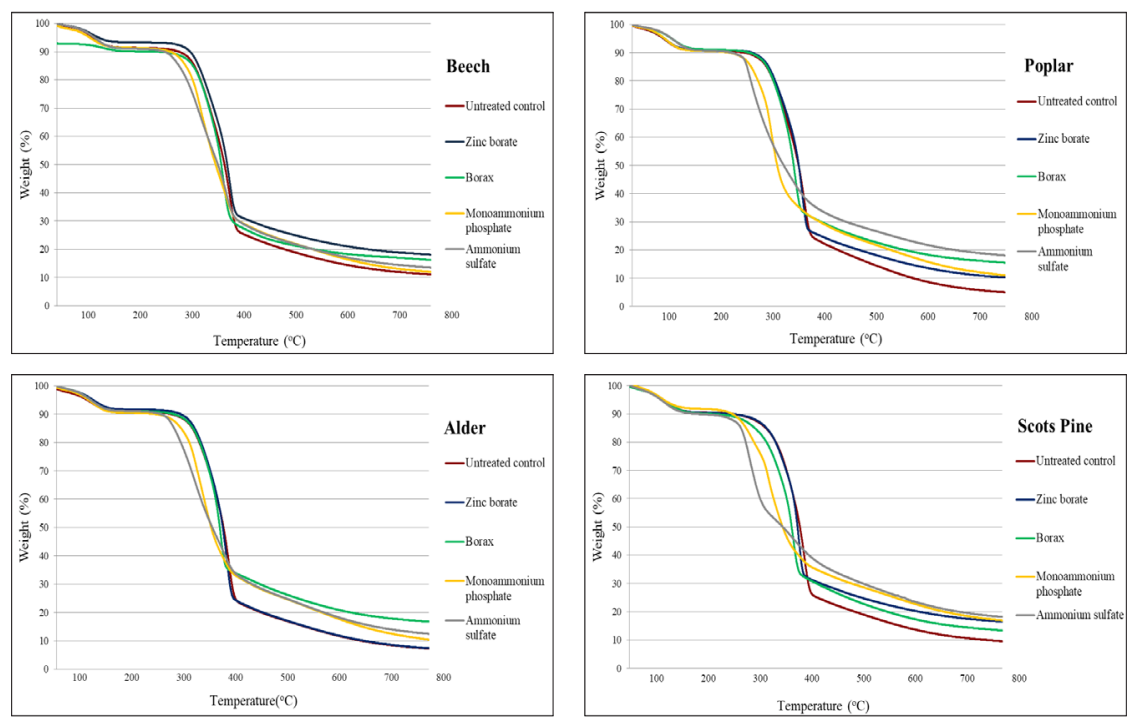

Figure 3: Thermogravimetric curves of veneers treated fire retardant chemicals.

Table 4: The results of thermal degradation of the veneers treated the fire retardant chemicals.

\begin{tabular}{|c|c|c|c|c|c|}
\hline Veneer species & $\begin{array}{l}\text { Fire Retardant } \\
\text { Chemicals }\end{array}$ & $\begin{array}{c}\mathrm{Ti}_{\mathbf{i}} \\
(\mathrm{C} \mathbf{C})\end{array}$ & $\begin{array}{l}T_{\max } \\
\left({ }^{\circ} \mathbf{C}\right)\end{array}$ & $\begin{array}{l}W_{\max } \\
(\%)\end{array}$ & $\begin{array}{l}\text { Residual } \\
\text { char } \\
(\%)\end{array}$ \\
\hline \multirow{5}{*}{$\begin{array}{c}\text { Beech } \\
\text { (Fagus orientalis } \\
\text { Lipsky) }\end{array}$} & Untreated control & 229.5 & 368.9 & 62.24 & 11.09 \\
\hline & Zinc Borate & 231.1 & 368 & 57.79 & 18.13 \\
\hline & Borax & 228.7 & 351.4 & 57.1 & 16.2 \\
\hline & MAP & 227.9 & 361.8 & 62.45 & 12.03 \\
\hline & Ammonium sulfate & 227.6 & 361.7 & 61.4 & 13.56 \\
\hline \multirow{5}{*}{$\begin{array}{c}\text { Alder } \\
\text { (Almus glutinosa } \\
\text { subsp. barbata) }\end{array}$} & Untreated control & 233.9 & 370.3 & 64.15 & 7.25 \\
\hline & Zinc Borate & 235.5 & 365.3 & 63.23 & 7.36 \\
\hline & Borax & 233.4 & 349.7 & 54.29 & 16.73 \\
\hline & MAP & 180.1 & 311.1 & 40.49 & 10.44 \\
\hline & Ammonium sulfate & 178.7 & 358.2 & 58.75 & 12.47 \\
\hline \multirow{5}{*}{$\begin{array}{c}\text { Poplar } \\
\text { (Populus deltoides I- } \\
77 / 51 \text { clone) }\end{array}$} & Untreated control & 231.4 & 370.4 & 64.63 & 5.02 \\
\hline & Zinc Borate & 230.6 & 363.6 & 62.49 & 10.22 \\
\hline & Borax & 234.5 & 347.8 & 55.24 & 15.54 \\
\hline & MAP & 194.1 & 289.9 & 39.93 & 10.96 \\
\hline & Ammonium sulfate & 184.7 & 238.7 & 19.41 & 18.12 \\
\hline \multirow{5}{*}{$\begin{array}{c}\text { Scots pine } \\
\text { (Pimus sylvestris L.) }\end{array}$} & Untreated control & 180.7 & 376.6 & 62.47 & 9.54 \\
\hline & Zinc Borate & 177.5 & 360.5 & 57.1 & 16.47 \\
\hline & Borax & 178.8 & 348.6 & 55.67 & 13.35 \\
\hline & MAP & 180 & 290.5 & 33.63 & 16.97 \\
\hline & Ammonium sulfate & 178.8 & 245.5 & 26.95 & 18.1 \\
\hline
\end{tabular}

The sharp decrease in thermogravimetric curves for the untreated control groups was seen between $180-380^{\circ} \mathrm{C}$ due to degradation of cellulose, hemicelluloses and lignin. Sinha et al. (2000) reported that the hemicelluloses decomposed easily to form gaseous products $\left(\mathrm{CO}, \mathrm{CO}_{2}\right.$, condensable vapors, and etc.) between $200-280^{\circ} \mathrm{C}$. Degradation of the hemicelluloses also causes the organic acid especially acetic acid formation. Acetic acid formation accelerates the decomposition of polysaccharides by means of acting as depolymerization catalyst (Brosse et al. 2010, Esteves and Pereira 2008). In temperature range between $250-300^{\circ} \mathrm{C}$, the other main components of the wood products (lignin and cellulose) are 
degraded and gas, tar and char are produced during the pyrolysis (Pétrissans et al. 2014). In this study, untreated control groups gave similar results.

There are many theories that proposed to explain the mechanism of fire retardancy of chemicals. These theories are classified into five categories: Barrier theories, thermal theories, dilution by noncombustible gases theories, free radical trap theories and increased char/reduced volatiles theories. Generally, fire retardancy mechanism of the chemicals could operate by the combination of these theories (LeVan 1984). The most acceptable theory which is called "chemical theory" suggests that the retardant chemicals operate by altering the pyrolysis of wood, increasing of char amount and causing the formation of less volatile and combustible vapors (LeVan and Winandy 1990). Also, according to Kollman and Cote (1968) all known flame retardant chemicals increased charring of wood at relatively low temperatures, thus improving thermal insulation. In Table 4, it was seen that all of the fire retardant chemicals gave higher char amounts than untreated control panels. As stated by NIIR (2017), fire retardant chemicals lower the temperature at which pyrolysis occurs, directing the degradation pathway toward more char production and fewer volatiles. The pyrolysis reactions generally occur at low temperatures for the treated wood compared to the untreated wood (LeVan and Winandy 1990, Holmes 1977). According to the temperature of the initial weight loss of pyrolysis $\left(\mathrm{T}_{\mathrm{i}}\right)$ and maximum degradation temperature $\left(\mathrm{T}_{\max }\right)$ in Table 4 , the pyrolysis of untreated veneer sheets generally began at higher temperatures than for treated veneer sheets.

The highest residual char amounts were obtained from ammonium sulfate for poplar and Scots pine; zinc borate for beech; borax for alder,. Boron materials as fire retardant chemicals were investigated by several researchers during the last decades (Tomak et al. 2012, Tondi et al. 2014, Salman et al. 2014, Yuksel et al. 2014, Istek et al. 2013, Roth et al. 2007, Jin et al. 2014, Qu et al. 2011). Parallel to the previous studies, our results showed that the impregnation of boron materials (Zinc borate and borax) enhanced the resistance against fire (Uner et al. 2016). Use of borates promotes the formation of CO and decrease $\mathrm{CO}_{2}$ amount during the pyrolysis (Uysal and Ozciftci 2004). Gao et al. (2006) stated that boron material is protected with a physical mechanism; the melted boron material results in a film layer which inhibits the access of oxygen and temperature to material.

\section{CONCLUSIONS}

Increased surface roughness values of the veneer sheets were obtained after fire retardant treatment. Among the fire retardant chemicals used in the study, boron treated groups exhibited the highest surface roughness values. Surface roughness of veneer sheets is extremely important on the product quality. Also, the fire retardant chemicals caused colour changes on surface of veneer sheets. It can significantly affect the wettability of the surface, the quality of gluing, and adhesion in plywood manufacture. Therefore, the effect of fire retardant chemicals on the surface roughness should be considered during manufacturing.

It was observed that fire retardant chemicals increased the thermal conductivity values of the veneer sheets when compared to the control groups of each wood species. Among the fire retardant chemicals used in the study, ammonium treated test groups gave the highest thermal conductivity values compared to boron treated groups. Fire retardant chemicals may increase the thermal conductivity of the wood to dissipate the heat from the surface faster than it is supplied by igniting source, or they may affect chemical and physical changes so that heat is absorbed by the chemical, preventing the wood surface from igniting (NIIR 2017). The increase of thermal conductivity can provide a significant advantage especially in the use of conductivity required areas such as wood buildings. According to TGA results, all fire retardant chemicals increased residual char amounts. Among the fire retardant chemicals used in the study, boron treated groups gave the highest residual char amounts for beech and alder. For poplar and Scots pine, highest residual char was observed in ammonium sulfate treated groups. 


\section{ACKNOWLEDGEMENTS}

Some results of this study were presented in Third National Furniture Congress held by Selçuk University, Konya, 2015. The authors acknowledge the partial financial support of this study by TUBITAK (The Scientific and Technical Research Council of Turkey) (Project No: 112O819).

\section{REFERENCES}

ASTM International.2004. Methods of Measuring Thermal Conductivity, Absolute and Reference Method ASTM C-518. 2004. ASTM International: West Conshohocken, USA.

Aydin, I. 2004. Effects of some manufacturing conditions on wettability and bonding of veneers obtained from various wood species. Ph.D., Karadeniz Technical University, Trabzon, Turkey.

Aydin, I.; Colakoglu, G. 2005. Effects of surface inactivation, high temperature drying and preservative treatment on surface roughness and colour of alder and beech wood. Applied Surface Science 252 (2): 430-440.

Aydin, I.; Colakoglu, G. 2008. Variations in bending strength and modulus of elasticity of spruce and alder plywood after steaming and high temperature drying. Mechanics of Advanced Materials And Structures 15(5): 371-374.

Ayrilmis, N., Korkut, S., Tanritanir, E., Winandy, J.E., Hiziroglu, S. 2006. Effect of various fire retardants on surface roughness of plywood. Building and Environment 41: 887-892.

Brosse, N.; El Hage, R.; Chaouch, M.; Petrissans, M.; Dumarcay, S.; Gérardin, P. 2010. Investigation of the chemical modifications of beech wood lignin during heat treatment. Polymer Degradation and Stability 95 (9): 1721-1726.

Burtin, P.; Allemand, C.J.; Charpentier, J.P.; Janin, F. 1998. Natural wood colouring process in Juglans sp. (J. nigra, J. regia and Hybrid J. nigra 23 J. regia) depends on native phenolic compounds accumulated in transition zone between sapwood and heartwood. Trees 12 (5): 258-264.

Deutsches Institut für Norming. DIN. 1990. Determination of Values of Surface Roughness Parameters R, R, Rmax Using Electrical Contact (Stylus) Instruments, Concepts and Measuring Conditions DIN 4768. 1990. Deutsches Institut für Norming: Berlin, Germany.

Dundar, T.; Ayrilmis, N.; Candan, Z. 2008. Evaluation of surface roughness of laminated veneer lumber (LVL) made from beech veneers treated with various fire retardants and dried at different temperatures. Forest Products Journals 54 (1/2): 71-76.

Esteves, B.M.; Pereira, H.M. 2008. Wood modification by heat treatment: A review. BioResources 4 (1):370-404.

Fateh, T.; Rogaume, T.; Luche, J.; Richard, F.; Jabouille, F. 2013. Kinetic and mechanism of the thermal degradation of a plywood by using thermogravimetry and Fourier-transformed infrared spectroscopy analysis in nitrogen and air atmosphere. Fire Safety Journal 58 (May 2013): 25-37.

Gao, M.; Sun, C.Y.; Wang, C.X. 2006. Thermal degradation of wood treated with flame retardants. Journal of Thermal Analysis and Calorimetry 85 (3): 763-769.

Gu, H.M.; Zink-Sharp, A. 2005. Geometric model for softwood transverse thermal conductivity. Part I. Wood and Fiber Science 37 (4): 699-711.

Hagen, M.; Hereid, J.; Delichatsios, M.A.; Zhang, J.; Bakirtzis, D. 2009. Flammability assessment of fire-retarded Nordic Spruce wood using thermogravimetric analyses and cone calorimetry. 
Fire Safety Journal 44 (8): 1053-1066.

He, X.; Li, X.; Zhong, Z.; Yan, Y.; Mou, Q.; Yao, C.; Wang, C. 2014. The fabrication and properties characterization of wood-based flame retardant composites. Journal of Nanomaterials 2014: $1-6$.

Holmes, C.A. 1977. Effect of fire-retardant treatments on performance properties of wood. Wood technology: chemical aspects. American Chemical Society.

Hunter Labs. 1996. Hunter Lab Colour Scale. Insight on Colour. Reston, VA, USA: Hunter Associates Laboratories. 8(9):1-4. Available https://support.hunterlab.com/hc/en-us/article attachments/201440625/an08_96a2.pdf

Ishiguri, F.; Maruyama, S.; Takahashi, K.; Abe, Z.; Yokota, S.; Andoh, M.; Yoshizawa, N. 2003. Extractives relating to heartwood color changes in sugi (Cryptomeria japonica) by a combination of smoke-heating and UV radiation exposure. J Wood Sci 49: 135-139.

Istek, A.; Aydemir, D.; Eroglu, H. 2013. Combustion properties of medium-density fiberboards coated by a mixture of calcite and various fire retardants. Turkish Journal of Agriculture and Forestry 37 (5): 642-648.

Jin S.; Yan, L.; Jing-Yu, W.; Fei W.; Zhen-Zhong, G. 2014. Fire resistance of boron-containing fire-retardant by TG analysis. Journal of Chemical and Pharmaceutical Research 6 (1): 332-337.

Kamke, A.F.; Zylkowoski, S.C. 1989. Effects of wood-based panel characteristics on thermal conductivity. Forest Products Journal 39 (5): 19-24.

Kawasaki, T.; Kawai, S. 2006. Thermal insulation properties of wood-based sandwich panel for use as structural insulated walls and floors. Journal of Wood Science 52 (1): 75-83.

Kol, H.S.; Ozcifci, A.; Altun S. 2008. Effect of some chemicals on thermal conductivity of laminated veneer lumbers manufactured with urea formaldehyde and phenol formaldehyde adhesives. Kastamonu University J of Forestry Faculty 8 (2): 125-130.

Kol, H.S.; Altun, S. 2009. Effect of some chemicals on thermal conductivity of impregnated laminated veneer lumbers bonded with poly (vinyl acetate) and melamine-formaldehyde adhesives. Drying Technology 27 (9): 1010-1016. Verlag.

Kollmann, F.F.P.; Cote, W.A. 1968. Principles of wood science and technology. Berlin: Springer-

Kruger, E.L.; Adriazola, M.K.O. 2010. Thermal analysis of wood-based test cells. Construction Building Materials 24 (6): 999-1007.

LeVan, S.L.; Winandy, J.E. 1990. Effect of fire retardant treatments on wood strength. Wood Fiber Science 22 (1): 113-131.

LeVan, S.L. 1984. Chemistry of Fire Retardancy. In The Chemistry of Solid Wood 207:531-574. Advances in Chemistry. American Chemical Society.

National Institute of Industrial Research. NIIR. 2017. The Complete Technology Book on Wood and Its Derivatives, Chapter 14: Chemistry of Fire Retardancy, National Institute of Industrial Research: Delhi, India.

Ozdemir, F.; Tutus, A.; Bal, B.C. 2013. Effect of fire retardants on thermal conductivity and limited oxygen index of high density fiberboard. SDU Faculty of Forestry Journal 14 (2): 121-126.

Ozkaya, K.; Ilce, C.A.; Burdurlu, E.; Aslan, S. 2007. The effect of potassium carbonate, borax and wolmanit on the burning characteristics of oriented strandboard (OSB). Construction and Building Materials 21(7): 1457-1462.

Pétrissans, A.; Younsi, R.; Chaouch, M.; Gérardin, P.; Pétrissans, M. 2014. Wood 
thermodegradation: Experimental analysis and modeling of mass loss kinetics. Maderas-Cienc Tecnol 16 (2): $133-148$.

Qu, H.; Wu, W.; Wu, H.; Xie, J.; Xu J. 2011. Study on the effects of flame retardants on the thermal decomposition of wood by TG-MS. Journal of Thermal Analysis and Calorimetry 103 (3): 935-942.

Resch, H.; Hansmann, C.; Pokorny M. 2000. The colour of wood from white oak. Holzforschung und Holzverwertung 52 (1): 13-15.

Roth, M.; Schwarzinger, C.; Mueller, U.; Schmidt, H. 2007. Determination of reaction mechanisms and evaluation of flame retardants in wood-melamine resin-composites. Journal of Analytical and Applied Pyrolysis 79 (1): 306-312.

Rowell, R.M.; Levan-Green, S. 2005. Thermal properties. In: Rowell RM, editor. Handbook of wood chemistry and wood composites, New York, Boca Raton and Florida: Taylor and Francis Group Inc: Chapter 6.

Salman, S.; Pétrissans, A.; Thévenon, M.F.; Dumarcay, S.; Perrin, D.; Pollier, B.; Gérardin, P. 2014. Development of new wood treatments combining boron impregnation and thermo modification: effect of additives on boron leachability. European Journal of Wood and Wood Products 72 (3): 355365.

Simsek, H.; Baysal, E. 2012. An investigation on colour and gloss changes of wood impregnated with borates. Wood Research 57 (2): 271-278.

Sinha, S.; Jhalani, A.; Ravi, M.R.; Ray, A. 2000. Modelling of pyrolysis in wood: a review. SESI Journal 10 (1): 41-62.

Stevens, R.; Es, D.S.; Bezemer, R.; Kranenbarg, A. 2006. The structure-activity relationship of fire retardant phosphorus compounds in wood. Polymer Degradation and Stability 91 (4): 832-841.

Tomak, E.D.; Baysal, E.; Peker, H. 2012. The effect of some wood preservatives on the thermal degradation of Scots pine. Thermochimica Acta 547 (2012): 76-82.

Tondi, G.; Haurie, L.; Wieland, S.; Petutschnigg, A.; Lacasta, A.; Monton, J. 2014. Comparison of disodium octaborate tetrahydrate-based and tannin-boron-based formulations as fire retardant for wood structures. Fire and Materials 38 (3): 381-390.

Uner, I.H.; Deveci, I.; Baysal, E.; Turkoglu, T.; Toker, H.; Peker, H. 2016. Thermal analysis of Oriental beech wood treated with some borates as fire retardants. Maderas-Cienc Tecnol 18 (2): 293304.

Uysal, B.; Kurt, S.; Kol, H.S.; Ozcan, C. 2008. Thermal conductivity of poplar impregnated with some fire retardant. Teknoloji 11 (4): 239-251.

Uysal, B.; Ozciftci, A. 2004. The effects of impregnation chemicals on combustion properties of laminated wood material. Combustion Science and Technology 176 (1): 117-133.

Yao, C.H.; Wu, Y.Q.; Hu, Y.C. 2012. Flame-retardation characteristics and mechanisms of three inorganic magnesium compounds as fire-retardant for wood. Journal of Central South University of Forestry and Technology 32 (1): 18-23.

Yeo, H.; Smith, W.B. 2003. Effect of temperature and moisture content on the discoloration of hard maple lumber, in: Proceedings of Eighth International IUFRO Wood Drying Conference, pp 455458.

Yildiz, S.; Tomak, E.D.; Yildiz, U.C.; Ustaomer, D. 2013. Effect of artificial weathering on the properties of heat treated wood. Polymer Degradation and Stability 98 (8): 1419-1427.

Yuksel, M.; Baysal, E.; Toker, H.; Simsek, H. 2014. Combustion characteristics of Oriental beech wood impregnated with commonly used borates. Wood Research 59 (1): 39-49. 